\title{
Reshaping the outdoors through education: exploring the potentials and challenges of ecological restoration education
}

\author{
Andreas Skriver Hansen ${ }^{1}$ (D) $\cdot$ Mattias Sandberg $^{2}$ (D)
}

Published online: 26 November 2019

(C) The Author(s) 2019

\begin{abstract}
This paper explores and critically discusses a new concept with relevance to outdoor and environmental education: Ecological Restoration Education (ERE). The background of ERE is a recently launched project by the Swedish Anglers Association (SAA) called 'Skolbäcken' with an aim to teach children about fish and fish habitats, and how to protect and conserve both, through practical restoration activities. The project is a reaction to an awakening concern about children's reduced contact with and understanding of nature, both in the Scandinavian countries and elsewhere in the world. With a point of departure in this concern and project Skolbäcken, the paper explores the idea and practice of ERE, drawing from its conceptual roots; 'ecological restoration' and 'outdoor education'. Results show a concept that is both timely and relevant as it not only emphasizes the critique of the children-nature disconnect, but also contributes with strategies to meet the critique with solutions that are appreciated both by the children and their teachers. However, there are also important challenges, including concerns about normative education and the 'projectification' of ERE and how these factors may influence the short or long term success and potential continuation of ERE as a learning strategy in schools. Future needs in terms of further grounding of ERE are also discussed.
\end{abstract}

Keywords Outdoor education · Restoration · Children - School $\cdot$ Leisure fishing · Outdoor NGO $\cdot$ Landscape

Andreas Skriver Hansen

andreas.hansen@geography.gu.se

Mattias Sandberg

mattias.sandberg@geography.gu.se

Extended author information available on the last page of the article 


\section{Introduction}

In the Nordic countries and elsewhere in the world, there is an awakening concern about children's reduced contact with and understanding of nature ${ }^{1}$ (Giusti et al. 2018; Louv 2006; Sandberg 2012; Skår et al. 2016). The diminishing direct contact with 'the more-than human world' ('green-blue areas', plants, animals, etc.) is associated with deteriorating mental and physical health, as well as reduced emotional affinity towards nature (Soga and Gaston 2016). Although the explanations behind this development, which Pyle (2002) famously referred to as the "extinction of experience" (p. 312), are not fully comprehended, some identified barriers to nature contact usually highlighted are: a) increased urbanisation and reduced access to green-blue areas; b) increasing possibilities for digital entertainment, communication and information; c) overscheduling of leisure activities; and d) increased concern for children's safety in public spaces (Soga and Gaston 2016).

Importantly for the context of this article, there are also concerns about growing barriers to outdoor education in schools, that is, outdoor teaching and learning activities that emphasise interaction between direct experience and reflection (Faskunger et al. 2018; Sandberg and Hansen 2018). Some of the barriers to outdoor education identified by teachers themselves include lack of confidence in teaching outdoors, lack of time and resources, and inflexible curriculums (Fägerstam 2012).

In order to meet these concerns and highlight the benefits of outdoor education, the Swedish Government has set ten national goals for outdoor recreation (Swedish Government 2012). For example, goal number 8 reads: "A rich outdoor life in the school." Meanwhile, several of Sweden's outdoor and nature conservation organisations (also known in Sweden as outdoor non-government organisations [NGOs]) are creating initiatives to introduce children to the joy of nature contact. For example, the Society for Nature Conservation teaches educators in outdoor pedagogics and the Swedish Hunting Association teaches about ecological connection through the lens of hunting.

Typical for these initiatives is that they are project based and explicitly target schools, and thus can be seen in the light of an ongoing trend of increased NGO influence in schools due to decentralization of school activities, increased autonomy as well as pressure on performance and competition between schools (cf. Yemini and Sagi 2015). The school projects initiated by outdoor NGOs typically emphasise the role of outdoor education as a way to foster active life-styles as well as environmental interest and learning through direct encounters with and experiences of nature. This can be seen in several both historical and contemporary projects, such as school children planting forests and creating school gardens (Åkerblom 2005; Kardell 2004). The difference between historical and contemporary projects is that the connection to ecological knowledge and understanding is more explicitly highlighted today, impelled by greater concern and knowledge about, for example, loss of biodiversity and climate change.

\footnotetext{
${ }^{1}$ We are following the Beery et al. 2017 definition of nature (with reference to Maller et al. 2006, p. 46; Keniger et al. 2013): an organic environment where the majority of ecosystem processes are present (e.g., birth, death, reproduction, relationships between species). This definition includes everything from habitats and wilderness areas to farms and gardens, and also spans the spectrum from the largely nonhuman to the heavily human, an especially important aspect in this paper as we focus on deliberate 'improvements' of nature/ecosystems in the name of ecological restoration.
} 
Among the initiatives from Sweden's outdoor NGOs is a project called 'Skolbäcken' (literally meaning 'School Creek') by the Swedish Anglers Association (SAA) with a focus on ecological restoration activities. The aim of the project is to teach children about fish and fish habitats, and how to protect and conserve both. The SAA's own educators bring the school children to water areas where they assist in ongoing fish restoration projects run by the SAA. The children contribute to the benefit and survival of the fish and their habitats through their efforts, while they also play and have fun during the activities.

The project clearly has many similarities with school projects launched by other outdoor NGOs in Sweden. However, there is an important difference in that the Skolbäcken project explicitly focuses on ecological restoration and the work performed by the children directly contributes to fish habitat restoration. This sets the project apart from other educational projects initiated by outdoor NGOs, which are mostly about outdoor games and play, with some general educational elements. In the Skolbäcken project, focus is instead on practical restoration work as the main pedagogic tool. A new concept and practice, at least so in a Swedish educational context, is thereby born, which we call ecological restoration education (ERE).

The focus of this paper is to explore the ideas, practices and potential of ERE using Skolbäcken as an example. The ideas developed in this paper are built on an evaluationreport of Skolbäcken completed during the spring of 2018 (Sandberg and Hansen 2018). In this small-scale evaluation, three school-classes participating in Skolbäcken were observed; follow-up interviews with the participating children, their teachers and SSAeducators were made; and an on-line survey was administered to all teachers participating in Skolbäcken. The results indicate that Skolbäcken have promising results in terms of learning and that the children as well as the teachers appreciate being active as well as contributing something positive to the life in waters nearby their school and homes. However, the understanding of the concept of ERE and its potential theoretical couplings and outreach needs further exploration. Hence, this paper should be seen as an explorative conceptual paper with a focus on learning more about ERE, that is the possibilities, from an educational perspective, of combining outdoor education and ecological restoration.

The paper begins by outlining ERE as a concept and providing an understanding of the wider context and emergence of ERE by briefly describing a few similar projects. Second, the Skolbäcken project is introduced with a specific focus on how it succeeds in combining restoration and educational activities. Third, the conceptual roots of the concept are discussed in more detail by giving focus to its main conceptual roots: ecological restoration and outdoor education. Finally, key reflections around potentials and challenges of ERE are discussed before the paper concludes with thoughts for the future role and implications of ERE.

\section{Defining ecological restoration education}

We define ERE as a pedagogical idea and approach with a strong emphasis on active participation of students in ecological restoration of degraded ecosystems, and where the restoration activities are deliberately promoted as a method to teach about ecosystems and the role of humans in affecting them (both positively and negatively). Like other outdoor education approaches, ERE is an active form of learning that builds on direct 
experiences in and with the natural environment as well as on environmental knowledge and engagement. What sets ERE apart from other outdoor education approaches is the direct and deliberate interventions of students altering and improving ecosystems, and in so doing, learning more about them. In order to alter an ecosystem deliberately in a profound and structured way, the educators usually need permission from landowners and/or authorities, something that of course makes this educational approach challenging. Furthermore, the restoration work performed by the children has to align with curriculum learning activities. This the educators have accomplished through their own educational training and executed through the more informal learning situation created in Skolbäcken. ERE thus becomes a new pedagogical approach in school.

We use outdoor education as our overarching frame for capturing different forms of formal and informal outdoor teaching and learning activities. Outdoor education, according to Sandell and Öhman (2013, p 36), includes for example "adventure education" and "outdoor learning," and "has long been regarded as an important tool for public environmental concern." In Sweden and other Nordic countries, there are strong ties between outdoor education, the broader cultural tradition of outdoor recreation ('friluftsliv') and the public right of access (in Swedish: 'allemansrätten'). The public right of access allows people to traverse land and water, light fires and camp for a day as long as the rule "Do not disturb, Do not destroy" is respected. Although the public right of access is inscribed in law, its limits can be defined as a "free space" between restrictions given by economic interests, privacy in homes, preservation and different landscape uses. From an educational perspective, this means that limits to the public right of access has to be learned in a landscape setting, where educators can adjust different activities in relation to the situation (Sandell and Öhman 2010).

Looking outwards, ERE has similarities with other known educational ideas and practices. For instance, in Denmark, there are examples going back to the 1980s of moving school classes into nature for a day. The main educational project doing this is today is called "Skoven i skolen" (in English: The forest in school), which is run by an established organization for and of educators (www.skoven-i-skolen.dk). The aim of the organization is to provide teachers with both practical and theoretical information and inspiration to perform teaching in the outdoors, and offers both books, courses and movies to help them plan the day in the outdoors. While there are strong similarities with the Skolbäcken project, especially when it comes to activities performed outdoors, there are also important differences. The main one is that Skoven i skolen mainly focuses on outdoor activities in general, while Skolbäcken has a direct focus on ecological restoration in combination with education, which therefore makes it a more constructive type of outdoor education.

ERE also shares similarities with the ideas and concepts of outdoor environmental education (OEE) and critical OEE. OEE focuses on bringing together educational experiences and activities in the outdoors with various environmental themes, such as learning about different species, habitats, ecosystems, etc. and can perhaps be said to be the main inspiration behind outdoor school classes with a focus on understanding the physical landscape and related environmental issues (Stewart 2008). Critical OEE keeps this focus but adds a deeper layer in terms of both the learning process and outcomes. Specifically, the critical perspective does not only explain the physical world and its conditions, but also sets it in a larger context of human-nature relationship and dependency, to be reflected upon after the meeting with or activity in nature (Thomas 
2005). ERE shares many features with OEE and critical OEE, but is still different from them in important ways. While OEE and critical OEE explain the educational meeting with the environment in more general and conceptual terms, ERE has a more practicebased focus, as it not only describes the educational component, but also includes the bodily, physical meeting with nature, the outcomes of this meeting, and what it means, both for the active children (the educational-constructive part) and for the restored ecosystems. In this way, we see an important difference between the concepts, one that supports both OEE and critical OEE, but also provides a new, more active angle. In that sense, ERE has more similarities with another OEE, namely outdoor experiential education, which is also better known as "learning by doing or experience"-focused education (Eyler 2009), as the children, through ERE, learn about the environments they work with and what their efforts result in.

\section{International examples of ecological restoration education}

While the idea of combining ecological restoration and outdoor education seems novel in a "modern" outdoor education context in Sweden, similar yet not exactly the same type of projects can be identified from around the world. In order to get an overview, a range of educational approaches and examples from various academic journals, webpages and professionals with long experience of outdoor education were examined or contacted. Focus was to identify case studies where students have been invited to work with restoring ecosystems (or similar type of work) in order to improve the environment, increase their ecological literacy and connect with nature and the local environment, acting as stewards for the land they are restoring. It is important to note that the produced list of examples is not exhaustive and that there are likely to be several other, similar projects around the world, especially local projects that are never reported or published in academic circles. In fact, the examples have been rather difficult to find, small in scale and are often, with a few exceptions, one-off projects with little or no continuation.

Beginning in the USA, a project on prairie restoration has been reported (Archie 2003), while on a more theoretical level, Cramer (2008) and Knackmuhs et al. (2017) have introduced the concept of "service-learning," which has strong links to experiential education. Service-learning concerns students engaging in activities that benefit and contribute to the local community while stimulating student learning and growth, and therefore often has a strong environmental focus. In another project called Earth Partnership for Schools, the aim is to (re)establish the connection between children and nature through various restoration and stewardship activities (Bauer-Armstrong 2016; Hall and Bauer-Armstrong 2010). School children participate by first studying native species, habitats and ecosystems, which among other things includes analysing soil compositions and vegetation, before moving on to actual restoration activities, such as planting seeds or removing invasive species, and reintroducing native ones. Through the combination of observations and practical restoration activities, the project owners hope that the children get a better understanding of the importance of their efforts. 
Another example can be found in Japan, where a few successful projects involve school children participating in restoration of old wetlands or habitats for the wild ibis (Ministry of the Environment 2009). In the wetland example, the children learn about rare species and the history of the wetlands in order to continue the restoration work that former generations began. In the ibis project, the children work with habitat improvement such as biotope construction and low-chemical farming. Both projects are locally initiated and built on collaborations between schools, environmental associations and local authorities.

In Russia, Greenpeace initiated a project in 2002 called "Kids for Forest Project" with hundreds of participants and with an aim to have school children reforest areas that have seen deforestation in both European and Asian Russia (Greenpeace 2013). The children manage small nurseries for tree saplings at school, which are then planted and followed by the children throughout their school time. The project is a collaboration between Greenpeace Russia and schools around the country, and has spawned several planting events throughout Russia as well as in Ukraine and Belarus.

In Costa Rica, Cruz and Segura (2010) have introduced the concept of "biocultural restoration," which involves educating local school children (and other community members) about resource use and ecosystems. Field based workshops work to strengthen the bioliteracy among the children, making them better equipped to make sound environmental decisions in the future.

Finally, in Denmark, the Fishing Zealand Association has arranged activities that are very similar to the efforts seen in project Skolbäcken, although not on the same scale or as organized (Michaelsen 2014). Children are taken to a small creek, where they assist a local biologist in building spawning and hiding areas for sea trout. The children help by adding gravel and small stones to the water, while they also experience restoration work done by machines, recreating the banks in the creek.

To sum up, what unites all the above examples is the hope that by engaging in restoration work, the children obtain a sense of agency in the work they have done, encouraging continuing interest and creating a stronger bond with nature. Furthermore, as the work is based in real situations and problems, the children are able to see the relevance of different methods and different types of knowledge that they know from school subjects such as math, physical education and health, science, etc. In turn, the children not only obtain a better understanding of the importance of the restoration work they engage in, but they also learn to transfer and apply what they learn in school to activities that are important and relevant for society.

Another interesting observation is that most of the initiatives described here do not come from schools, but rather from outside stakeholders working with ecological restoration activities. One possible reason for this trend is that ecological restoration requires access to land and waters, through either ownership or collaboration with landowners and/or local authorities or NGOs. The outdoor NGOs are also inclined to promote their successful projects in order to spread their efforts and hence attract funding and new memberships. Schools, on the other hand, often lack both time and resources to do outdoor teaching, and further, they often struggle to ensure access to green areas with enough 
space to both teach and play. The stakeholders and the schools therefore have a mutual interest in working together.

\section{Fish habitat restoration as ecological restoration education: The example of Skolbäcken}

Project Skolbäcken was initiated by the SAA in 2016 with an aim to introduce school children to the importance of restoring habitats for fish populations. The SAA have over 60,000 members interested in leisure fishing, which includes a necessary concern for the resources and habitats that this activity relies on. As such, the SAA can be described as a hybrid between an outdoor recreation and conservation organisation. The two main goals of the association are to: a) stimulate interest in leisure fishing among children and youth; and b) create interest in as well as work with conservation and restoration of fish habitats, both practically and through initiating and supporting research. Traditionally, these two focus areas have been developed separately.

Projects targeting children and youth are often run voluntarily by members in local branches of the SAA. Other groups work with ecological restoration and monitoring, either in water areas owned by the association or managed by them on behalf of local authorities. The Skolbäcken project integrates these two areas of interest for the SAA, and with an increase in state funding for outdoor organizations as support, the SAA has taken the opportunity to combine them into a new educational project for school children.

Skolbäcken is primarily offered to children in grades 1-6 (7-12 years old) with the hope that the activities will stimulate their interest in fish through practical nature and fishing management activities. Since the start of the project in 2016, the SAA has brought thousands of children, primarily around the three largest cities in Sweden, to different types of water areas, including creeks, rivers, lakes and seashores.

Project Skolbäcken focuses on three main learning environments: ice, wetland and running water. On the ice, the children collect and build small piles of branches and twigs, which are sunk in order to create underwater spawning areas for small fish, such as perch. They also learn about basic safety issues related to being on the ice. Other children restore wetlands in order to create or improve play areas for pike stocks, which have dropped drastically along the Baltic Sea coast. The children visit wetlands (re-)created by the SAA, often in collaboration with local municipalities and other non-profit organizations. The children watch, pat and even kiss the pikes, which are weighed and measured before they are put back again. Running water is the third learning environment and here the children put gravel, pebbles and dead wood into running creeks and streams in order to create spawning areas and hiding places for trout. They also observe how fishing with electricity is carried out. Following this, the children are invited for a return visit in order to let them know what they have achieved and to consolidate the knowledge and experiences.

Skolbäcken usually starts with educators from SAA contacting schools near water areas where the SAA is already involved with restoration activities. After the schools and the SAA agree on a time and place, the class is invited for a morning or an afternoon session, usually lasting between two and three hours. Prior to the visit, the teacher is sent a short instruction booklet, which introduces what will happen during the 
day, how Skolbäcken connects to the curriculum learning goals and how the class can prepare themselves for the day outdoors. The educators from SAA then meet the children by the water area, which they will learn more about and help restore. Regardless of the learning environment (ice, wetland or running water), the session consists of the following main activities: games and play, possibilities to observe and learn more about fish, small breaks as well as practical fish and water restoration activities. At the end of the session, the children receive a diploma for their efforts. The experiences from the project have so far been promising and there are many indications that both teachers and the children appreciate participating in the project.

\section{Exploring the conceptual roots of ecological restoration education}

ERE is an amalgamation of "ecological restoration" and "outdoor education." Ecological restoration has its roots in the natural sciences where, for decades, it was an exclusive arena for researchers and other experts with a background in ecology and/ or biology. Ecological restoration has a long history in practice, going back to the 19th and early 20th centuries (Jordan et al. 1987; Palmer et al. 2016), but it was not until the late 1980s that the concept itself became pronounced, particularly when the Society for Ecological Restoration (SER) was founded in 1988 (Jackson et al. 1995). The SER now has its own scientific journal featuring international examples of ecological restoration projects and theory. A commonly used definition of ecological restoration promoted by the SER is "the process of assisting the recovery of an ecosystem that has been degraded, damaged, or destroyed" (Society for Ecological Restoration Science and Policy Working Group (2002) cited in Martin 2017).

Ecological restoration concerns the act of improving, saving or reviving an ecosystem that has undergone pressure, often human produced, such as from resource harvesting, infrastructure development, or tourism. This pressure often leads to damage of the ecosystem, or worse, degradation and finally destruction (e.g. through loss of key species or processes). In a world faced with an increasing number of anthropogenic pressures, where there are no longer any landscapes or natural systems unaffected by human activities, the task of restoring ecosystems has become more relevant and important than ever before. Within academia, ecological restoration aligns with conservation biology and more recently also the idea of rewilding, with a focus on protection of valuable ecosystems and restoration of natural habitats (Pires 2017).

Ecological restoration has also been criticized for a naïve and static understanding of nature. While nature is inherently dynamic, not least apparent from a climate historical point of view, an ecosystem can never be restored (in the true sense of the word) into a previous condition, only altered (Choi 2007). Although forces other than those derived from anthropogenic pressures can result in degraded ecosystems, actual restoration work inevitably involves human values, ethics, priorities, and most importantly, actions in the landscape. Hence, this is a field in need of insights from both the natural and the social sciences, as well as acceptance and even direct involvement from actors who in different ways depend on intact and healthy local ecosystems (Palmer et al. 2016).

In this context, the questions of "when" an ecosystem is deemed degraded and "how" restoration should be done, make ecological restoration a political issue that has sparked controversy (Martin 2017). This question of "who" should be responsible for 
the actual restoration work is also important, as there are large differences in ideals between different involved actors (Blicharska and Rönnbäck 2018).

It is important to acknowledge these political dimensions of ecological restoration, not least when introducing practical ecological restoration in an educational context. This is also emphasized by Martin (2017), who argues that a further crucial question for actors involved in ecological restoration is "why?" Transferring this to the project run by the SAA, an important question becomes: Why should school children involve themselves with restoration of fish habitats? What is in it for them as well as the schoolteachers? Wherein is the value that is created; value for whom and what? Coming up with meaningful answers to these questions ought to be a central part of the idea and practice of ERE.

Consequently, Martin (2017) stresses the importance of educators being transparent about both positive and negative effects and values of various restoration measures as well as why restoration measures are necessary in the first place. This is especially important when introducing ecological restoration in compulsory school subjects, as the children must understand why and how they can actively take part in altering the landscape through restoration activities.

Moving on to outdoor education, modern outdoor education has a relatively shorter history, going back to the 1970s, where it emerged in its current form (Adkins and Simmons 2002; Wattchow and Brown 2011). The emergence can be seen as a result of growing opportunities to perform outdoor activities during leisure time, which increased drastically in the post-war years (Emmelin et al. 2010). During this time, outdoor education became a focus and topic of discussion in schools, and seen as a way to extend and fill the school curriculum with new content and activities (Hammerman 1980). However, it was not until the 1970s that outdoor education was recognized formally as an educational approach and practise, not only in the school system, but also in the growing number of outdoor organisations that began to form in the late 1970s and onwards (Wattchow and Brown 2011). Meanwhile, outdoor education also received increased academic attention, becoming a field of research on its own, and is today a focus for many new educational initiatives, as emphasized earlier.

Outdoor education concerns educational content and activities performed in the outdoors. However, "outdoors" can mean many things, everything from the school yard to local forests or lakes outside the school area. There is no single definition, but rather various versions depending on the context (Wattchow and Brown 2011). One common trait, however, is the close relation to established concepts such as outdoor learning and environmental education with which outdoor education shares many of the same principles. One definition is offered by Gustafsson et al.:

Outdoor education is an environment-focused educational approach characterized by action-centred and thematic learning processes, often related to outdoor activities. It aims to foster learning through the interactions between emotions, actions and thoughts, based on practical observation in authentic situations. (Gustafsson et al. 2011, p. 7)

Many personal benefits of outdoor learning have also been identified, including physical activities, self-esteem, collaboration, socializing, de-stressing, tolerance and joy (Gustafsson et al. 2011). For school children, all these benefits are core 
values that cannot be taught but must be practiced and experienced, in this case through outdoor activities.

Outdoor education is thus more than just a question of performing teaching outdoors, as opposite to "indoor teaching," which is rarely spoken of. Indeed, it is a learning method that brings together conceptual, theoretic and experiential learning in an outdoor context, which becomes the context, focus and stimulation for various learning situations. The strength in highlighting the "outdoors" is that the outdoors lets educators choose direction of pedagogical focus, including a broad spectrum of landscape uses, ranging from passive observations to active activities such as counting trees, planting species or building a bridge across a stream.

Yet, outdoor education traditionally does not (or at least very rarely) include letting children actively and systematically restore landscapes and ecosystems through direct actions aiming at altering ecological conditions. But ERE does, and does so by adding and emphasizing the idea of "learning by doing", combining direct, sensory experience with reflection and theoretical learning. The idea and concept of ERE is therefore an interesting development, as it not only opens up for new pedagogic and educational opportunities, but also has a higher environmental and societal purpose of restoring important ecosystem functions.

\section{Potentials and challenges of ecological restoration education}

Our main argument is that the inclusion of ecological restoration in an educational context opens up for new and fruitful possibilities for outdoor learning. However, before taking a step further and beyond the exploration of the idea and practice of ERE itself, it is important to also highlight a few potentials and challenges concerning ERE. The most important potential of ERE that we discern is how it can shed new light on the role of humans in the biosphere - particularly stressing why and how we can act as socio-ecologically responsible citizens. For this to be achieved, an improved understanding of the relationship between human and nature from an early age is an important measure that ought to be prioritized in schools, and if the school does not take responsibility, by outdoor NGOs like the SAA. Participating in ERE can hopefully help children understand that human environmental impacts, and the responsibility for these, go beyond our role of "indirect" stewards of the biosphere, for example through being consumers and citizens. In this light, ERE can be seen as a practical way of demonstrating how it is possible to take an active role as a participant in the landscape and as positive co-producers of the nearby environment.

Of course, on a more critical note, one could not reasonably expect that a two-hour outdoor education-activity will have an immediate and profound effect on the children's world-views and understandings of human-nature relations. Nonetheless, we see the combination of the efforts made by SAA and the interest shown by schools to participate in Skolbäcken as part of a growing recognition of the fact that "large scale" environmental challenges, framed by a top-down and systematic perspective, need to be accompanied by embodied and everyday actions and an understanding of the "small scale" environment within reach (Chan et al. 2016; Hägerstrand 2001; Stenseke 2018). If the macro and micro aspects of our environmental relationships are not intertwined, we cannot expect children to learn to take responsibility for, let alone appreciate, the 
local (and global) environment. Efforts must be made to (re)connect children with their micro scale environment, as these small steps may turn into larger, but mindful ecological footprints later in life.

While the idea and practice of ecological restoration education seems straightforward and an inherently "good" practice that is difficult to dismiss, it also contains certain challenges. For example, ERE opens a discussion about responsibility and power. Who is actually responsible for teaching children in and about nature? One crucial challenge with ERE is connected to the fact that restoration work builds on idealistic and normative thinking. For instance, the SAA is an organisation with a strong pro-environmental worldview. It is therefore also a loaded worldview, which may go against (relative) objective teaching standards in school. Should that be allowed? And who should decide this? These questions are not easily answered as they are questions related to power and authority of interpretation and uses of the landscape, and the question of who ultimately has the right to educate children and, more importantly, what worldview they are presented with.

The issue is connected to another important discussion concerning why and how restoration activities themselves are carried out. This question was raised earlier, but is an important one, as restoration work is connected to certain landscape values and uses. And for each of these values and uses, there are people defending them or protesting against them. For instance, while the SAA has a pro-environmental worldview, this is not always shared by local landowners, who may be concerned that restoration work may be a hindrance for their own land uses and plans for development. In an educational setting, this entails that educators must thoroughly explain and work with this situation, while acknowledging that there will always be something gained and something lost when certain ecological structures and functions are prioritised over others. Transparency about potential outcomes when interfering in the dynamics of ecosystems is therefore important as it informs the children about the consequences of different choices when it comes to how the land is formed and used.

Another challenge is to keep the momentum going when it comes to introducing ERE in schools. At the moment, project Skolbäcken is experiencing widespread popularity among schools in Sweden, but it is still only in its test phase. This "projectification" of outdoor education holds many uncertainties, as it has not been done before and therefore there is nothing to compare it with. Furthermore, at the moment, the project is of a temporary nature, which means that it is difficult to change the current content and character of the project into something more permanent. More development of the ideas and practices of ERE must therefore be prioritized, both by the SAA and within academia, where the development of ERE can be studied in order to understand the value of the involved ecological work and educational aims.

In terms of the SAA's own contribution, there are already now indications of expanding the project to all parts of Sweden. But before this can happen, more knowledge about the ideas and practices of ERE is needed in order to develop and further anchor ERE not only in schools, but also among other outdoor NGOs. More work is therefore needed in the form of more and better collaboration between outdoor NGOs in Sweden, who have similar initiatives, but which are currently not coordinated in any way. If ERE could be made the common ground between the outdoor NGOs, it could have a major impact on how ERE can be developed and eventually become an integrated part of outdoor education and learning strategies in schools. 


\section{Final remarks}

In the beginning of this paper, the lack of connection between children and nature was emphasised to be a problem in general, but particularly so in school. Many reasons for this were mentioned, including lack of time, resources and confidence among teachers to teach outdoors. Even subjects like biology and physical education and health, which traditionally have featured outdoor content, often do not make use of the opportunities for learning that nature and the outdoors provide. The trend is worrisome, as children's diminished opportunity to learn about and experience nature first-hand becomes a contributing factor to the growing disconnection that is experienced and criticized in today's society.

In some countries, such as in Sweden, Denmark and Norway, the counteraction to this development has been to make schools more nature oriented, where schools locate parts of the teaching to nature areas and where activities take place in nature. However, these schools are far from representing the majority of the schools in all three countries. Consequently, it is important that initiatives by outdoor NGOs, such as SAA's Skolbäcken project, are offered as they function as a way to build a bridge between children and nature, reconnecting them through new knowledge and fun experiences. Skolbäcken is therefore both timely and relevant as it not only emphasizes the critique of the children-nature disconnect, but also contributes with strategies to meet the critique with solutions that are appreciated both by the children and their teachers.

In this paper, we put forward the argument that the idea and practice of ERE can be seen as an innovative pedagogical tool within the field of outdoor education. Although causal relationships between direct nature experience and environmental engagement are difficult to discern among children, this assumption and hope still underpins different outdoor education efforts, including SAA's hopes and expectations for Skolbäcken.

An argument for taking this initiative and engaging in the extensive work that is required in ERE lies in the importance of how and why we can act as socio-ecologically responsible citizens and thereby offering an example for future generations. In a world of rapid climate changes and fiery debates on the human responsibility for this trend, this is a particular important point to make, as our current footprints will leave undeniable marks in the future. Furthermore, from a school perspective, projects like Skolbäcken can open up doors not only to the local environment, but also to new kinds of experiences and learning opportunities. However, in this work, there are also important challenges to address, one being a concern about normative education (and the question of "why" in restoration work) and the other being about the "projectification" of ERE (and how this may influence the short or long term success and potential continuation of ERE as a learning strategy in schools). The next step therefore is to anchor ERE, both in schools and among outdoor NGOs as well as within academia.

Acknowledgements This research was supported by the Swedish Anglers Association (SAA) and the Unit for Human Geography at the University of Gothenburg. We wish to give special thanks to the SAA, and particularly Malin Kjellin and Jesper Taube at the SAA, for giving us constructive feedback on our work. 
Funding information Open access funding provided by University of Gothenburg. The study was partly funded by the Swedish Anglers Association (no grant number).

\section{Compliance with ethical standards}

Conflict of interest The authors received a research grant from the Swedish Anglers Association to perform an evaluation of Skolbäcken. This work was carried out during 2018. The SAA owns the project itself, but not the intellectual rights, including communication of the project results, which is shared between the SAA and the authors. This has been agreed upon by both parties.

Open Access This article is distributed under the terms of the Creative Commons Attribution 4.0 International License (http://creativecommons.org/licenses/by/4.0/), which permits unrestricted use, distribution, and reproduction in any medium, provided you give appropriate credit to the original author(s) and the source, provide a link to the Creative Commons license, and indicate if changes were made.

\section{References}

Adkins, C. \& Simmons, B. (2002). Outdoor, experiential, and environmental education: Converging or diverging approaches? Digest 2002-08-00. Charleston WV: ERIC Clearinghouse on Rural Education and Small Schools. (ERIC Digests in Full Text No. ED467713).

Åkerblom, P. (2005). Lära av trädgård. Pedagogiska, historiska och kommunikativa förutsättningar för skolträdgårdsverksamhet (Learning by Gardening. Educational, Historical and Communicative Conditions for School Gardens). Doctoral dissertation. Uppsala: SLU.

Archie, M. L. (2003). Advancing education through environmental literacy. Alexandria: Association for Supervision and Curriculum Development.

Bauer-Armstrong, C. (2016). Education through ecological restoration: Earth partnership engages youth as environmental stewards. Green Schools National Network. Retrieved from https:/greenschoolsnationalnetwork.org/education-ecological-restoration-earth-partnership-engagesyouth-environmental-stewards/Accessed 10 January 2019.

Beery, T. H., Raymond, C. M., Kyttä, M., Olafsson, A. S., Plieninger, T., Sandberg, M., Stenseke, M., Tengö, M., \& Jönsson, K. I. (2017). Fostering incidental experiences of nature through green infrastructure planning. $A M B I O, 46(7), 717-730$.

Blicharska, M., \& Rönnbäck, P. (2018). What factors enable or hinder engagement of civil society in ecosystem management? The case of 'pike factories' and wetland restoration in Sweden. Journal of Environmental Planning and Management, 61(5-6), 950-969.

Chan, M. A. K., Balvanera, P., Benessaiah, K., Chapman, M., Díaz, S., Gomez-Baggethun, E., Gould, R., Hannahs, N., Jax, K., Klain, S., Luck, W. G., Martín-Lopez, B., Muraca, B., Norton, B., Ott, K., Pascual, U., Satterfield, T., Tadaki, M., Taggart, J., \& Turner, N. (2016). Opinion: Why protect nature? Rethinking values and the environment. PNAS, 113(6), 1462-1465.

Choi, D. Y. (2007). Restoration ecology to the future: A call for new paradigm. Restoration Ecology, 15(2), $351-353$.

Cramer, J. R. (2008). Reviving the connection between children and nature through service-learning restoration partnerships. Native Plants, 9(3), 278-286.

Cruz, R. E., \& Segura, R. B. (2010). Developing the bioliteracy of school children for 24 years: A fundamental tool for ecological restoration and conservation in perpetuity of the Área de Conservación Guanacaste, Costa Rica. Ecological Restoration, 28(2), 193-198.

Emmelin, L., Fredman, P., Jensen, E. L., \& Sandell, K. (2010). Planera för friluftsliv - Natur, Samhälle, Upplevelser (planning for outdoor recreation - Nature, society, experiences). Stockholm: Carlsson Bokförlag.

Eyler, J. (2009). The power of experiential education. Liberal Education, 95(4), 24-31.

Fägerstam, E. (2012). Space and place perspectives on outdoor teaching and learning (doctoral dissertation). Linköping studies in Behavioural science no. 167. Linköping, Sweden: Linköping University.

Faskunger, J., Szczepanski, A. \& Åkerblom, P. (2018). Klassrum med himlen som tak. En kunskapsöversikt om vad utomhusundervisning betyder för lärande i grundskolan (Classroom with the sky as the cealing. A 
knowledge review of outdoor education role for learning in primary school). Skrifter från Forum för utomhuspedagogik nr 10. Linköping, Sweden: Linköping University.

Giusti, M., Svane, U., Raymond, C. M., \& Beery, T. H. (2018). A framework to assess where and how children connect to nature. Frontiers in Psychology. https://doi.org/10.3389/fpsyg.2017.02283.

Greenpeace Russia (2013). "Kids for Forest” Project, 2013 Report. Greenpeace Russia. Retrieved from https:/umweltstiftung-greenpeace.de/sites/default/files/Kids-for-Forests-Project-Report\%202013.pdf Accessed 10 January 2019.

Gustafsson, P. E., Szczepanski, A., Nelson, N., \& Gustafsson, P. A. (2011). Effects of an outdoor education intervention on the mental health of schoolchildren. Journal of Adventure Education and Outdoor Learning, 12(1), 63-79.

Hägerstrand, T. (2001). A look at the political geography of environmental management. In A. Buttimer (Ed.), Sustainable landscapes and Lifeways: Scale and appropriateness (pp. 35-58). Cork University Press: Cork.

Hall, R., \& Bauer-Armstrong, C. (2010). Earth partnership for schools: Ecological restoration and schools and communities. Ecological Restoration, 28(2), 208-212.

Hammerman, W. M. (Ed.). (1980). Fifty years of resident outdoor education, 1930-1980: Its impact on American education. Martinsville, IN: American Camping Association.

Jackson, L. L., Lopoukhine, N., \& Hillyard, D. (1995). Ecological restoration: A definition and comments. Restoration Ecology, 3(2), 71-75.

Jordan, W. R., Gilpin, M. E., \& Aber, J. D. (1987). Restoration ecology: A synthetic approach to ecological research. Cambridge: Cambridge University Press.

Kardell, L. (2004). Svenskarna och skogen: från baggböleri till naturvård. Del 2 (The Swedes and the forest: from baggböleri to nature conservation, part 2). Jönköping: Skogsstyrelsen.

Keniger, L. E., Gaston, K. J., Irvine, K. N., \& Fuller, R. A. (2013). What are the benefits of interacting with nature? International Journal of Environmental Resources and Public Health, 10(3), 913-935.

Knackmuhs, E., Farmer, J., \& Reynolds, L. H. (2017). Student outcomes of eco-restoration service-learning experiences in urban woodlands. The Journal of Experimental Education, 40(1), 24-38.

Louv, R. (2006). Last child in the woods: Saving our children from nature-deficit disorder. Chapel Hill: Algonquin Books of Chapel Hill.

Maller, C., Townsend, M., Pryor, A., Brown, P., \& St. Leger, L. (2006). Healthy nature healthy people: 'Contact with nature' as an upstream health promotion intervention for populations. Health Promotion International, 21(1), 45-54.

Martin, D. M. (2017). Ecological restoration should be redefined for the twenty-first century. Restoration Ecology, 25(5), 668-673.

Michaelsen, K. (2014). Potentialet ved at inddrage skolerne i naturgenopretning (the potential of including schools in nature restoration). Fishing Zealand. Retrieved from http://fishingzealand. $\mathrm{dk} /$ havorred/potentialet-ved-inddrage-skolerne-naturgenopretning/ Accessed 10 January 2019.

Ministry of the Environment (2009). Towards living in harmony with the natural environment. Retrieved from https://www.env.go.jp/en/nature/npr/nrp_japan/pdf/full.pdf Accessed 10 January 2019.

Palmer, M. A., Zedler, J. B., \& Falk, D. A. (2016). Foundations for restoration ecology (2nd ed.). Washington: Islands Press.

Pires, M. M. (2017). Rewilding ecological communities and rewiring ecological networks. Perspectives in Ecology and Conservation, 15(4), 257-265.

Pyle, R. M. (2002). Eden in a vacant lot: Special places, species and kids in the neighbourhood of life. In P. H. Kahn \& S. R. Kellert (Eds.), Children and nature: Psychological, sociocultural, and evolutionary investigations (pp. 305-327). Cambridge, Mass: MIT Press.

Sandberg, M. (2012). De är inte ute så mycket: Den bostadsnära naturkontaktens betydelse och utrymme $i$ storstadsbarns vardagsliv ('They are not outdoors that much'. Nature close to home - its meaning and place in the everyday lives of urban children.). Doctoral dissertation. Gothenburg: University of Gothenburg.

Sandberg, M., \& Hansen, A. S. (2018). Skolbäcken: Som ett rinnande vatten? Utvärdering av Sportfiskarnas satsning på naturvårdsinriktad utomhuspedagogik (Skolbäcken: An evaluation of the Swedish Anglers Association project on ecological restoration education). Stockholm: Sportfiskarna.

Sandell, K., \& Öhman, J. (2010). Educational potentials of encounters with nature: Reflections from a Swedish outdoor perspective. Environmental Education Research, 16(1), 113-132.

Sandell, K., \& Öhman, J. (2013). An educational tool for outdoor education and environmental concern. Journal of Adventure Education \& Outdoor Learning, 13(1), 36-55. 
Skår, M., Wold, C. L., Gundersen, V., \& O’Brien, L. (2016). Why do children not play in nearby nature? Results from a Norwegian survey. Journal of Adventure Education and Outdoor Learning, 16(3), 239255.

Society for Ecological Restoration Science and Policy Working Group (2002). The SER primer on ecological restoration. Society for Ecological Restoration. www.ser.org/

Soga, M., \& Gaston, K. J. (2016). Extinction of experience: The loss of human-nature interactions. Frontiers in Ecology and the Environment, 14, 94-101.

Stenseke, M. (2018). Connecting 'relational values' and relational landscape approaches. Current Opinion in Environmental Sustainability, 35, 82-88.

Stewart, A. (2008). Whose place, whose history? Outdoor environmental education pedagogy as "reading" the landscape. Journal of Adventure Education and Outdoor Learning, 8(2), 79-98.

Swedish Government. (2012). Mål för friluftslivspolitiken. Skr 2012/13:51 (political goals for outdoor recreation). Stockholm: Regeringskansliet.

Thomas, G. (2005). Traditional adventure activities in outdoor environmental education. Australian Journal of Outdoor Education, 9(1), 31-39.

Wattchow, B., \& Brown, M. (2011). A pedagogy of place: Outdoor education for a changing world. Melbourne: Monash University Press.

Yemini, M., \& Sagi, N. (2015). School-nongovernmental organization engagement as an entrepreneurial venture: A case study of Sunlight's engagement with Israeli schools. Educational Administration Quarterly, 51(4), 543-571.

Publisher's note Springer Nature remains neutral with regard to jurisdictional claims in published maps and institutional affiliations.

Andreas Skriver Hansen is a researcher at human at the University of Gothenburg, Sweden. His research interests include outdoor recreation planning and management, tourism, nature-human interactions and landscape theory with an emphasis on different landscape perceptions and experiences, uses and understandings. Andreas also work a lot with applied research, especially in connection to physical and environmental planning, and has published in Journal of Outdoor Recreation and Tourism, Scandinavian Journal of Hospitality and Tourism and PLAN.

Mattias Sandberg is a lecturer and researcher in human geography at the University of Gothenburg, Sweden. His research interests include landscape planning, political ecology, outdoor recreation, children's contact with nature, housing and segregation. Mattias often work in transdisciplinary research collaborations and has previously published papers in journals such as Journal of Environmental Management, Ambio, and Landscape and Urban Planning.

\section{Affiliations}

\section{Andreas Skriver Hansen ${ }^{1} \cdot$ Mattias Sandberg $^{2}$}

1 Unit for Human Geography, Department of Economy and Society, University of Gothenburg, Sweden, Viktoriagatan 13, 4th floor, Room 417, P.O. Box 625, SE-405 30 Göteborg, Sweden

2 Unit for Human Geography, Department of Economy and Society, University of Gothenburg, Sweden, Viktoriagatan 13, 5th floor, Room 512, P.O. Box 625, SE-405 30 Göteborg, Sweden 